\title{
The Theatre of Chaeronea and Rectilinear Koila
}

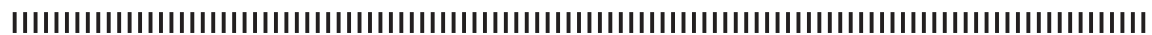

Marco Germani

$\mathbf{T}$ he theatre of Chaeronea, in Boeotia, has always been of great interest due to the rectilinear plan of its early structure. Excavations carried out in 2009 have enabled us to observe previously undiscovered phases of construction and parts of the building. Thanks to these surveys, we can now discuss the monument's creation and architectural evolution, concentrating on the redefinition of the theatre's koilon. This article aims to re-examine the structures of the theatre of Chaeronea, starting with an examination of some of the most interesting rectilinear koila in Greece. In recent years, excavations in continental Greek have led to a revival of the endless debate on rectilinear plans and on the relationships between fifthcentury theatres exhibiting plans with rectilinear staircases. Following the canonisation of the semi-circular plan, did all theatres suddenly take up the new model? When did the theatre of Chaeronea abandon its rectilinear shape to imitate the semi-circular theatres of the fourth century BC? Can we really imagine an immediate and sudden upsetting of theatre plans without considering the spread and reception times of the new model? How much did local needs and specificities influence the redefinition of old theatres? The following paper does not necessarily aim to answer all of these questions, but draws attention to certain issues arising from the Chaeronea theatre case. The small Boeotia town experienced its greatest economic and demographic development starting in the late first century BC. Evidently, however, consistent with a regional situation that was particularly active ${ }^{1}$ in theatre construction, it had already built its small theatre in the fifth century BC, despite its small size.

"There is no incontrovertible evidence for an orchestra circle before the theater at Epidauros was built at the end of the fourth century BC", concluded Gebhard ${ }^{2}$ in a long 1974 article on orchestra shapes in the most ancient Greek theatres. Her research came after a long series of studies on rectilinear plan theatres and was trailed by many other articles searching for common aspects that could be potentially attributable to a widespread

\footnotetext{
${ }^{1}$ Germani M. Boiotian theatres: an overview of the regional architecture, in Rune Frederiksen, Elizabeth R. Gebhard and Alexander Sokolicek (edd.), The Architecture of the Ancient Greek Theatre, Acts of an International Conference at the Danish Institute at Athens, 27-30 January 2012, Athens 2015. - PP. 351-365.

${ }^{2}$ Gebhard E. The form of the orchestra in the Early Greek theatre, in Hesperia, 1974, 43. - P. 440.
} 
model in the fifth century BC. More recently, Moretti, starting from the theatre of Dionysus on the slopes of the Athenian acropolis, took the opportunity to revisit and update the status quaestionis on theatres with rectilinear koila in Greece. Numerous hypotheses have been developed on the origin and spread of the rectilinear shape, and just as many theories on the transition to semi-circular koilon have been expressed ${ }^{1}$. What is widely accepted, however, is that, starting in the second half of the fourth century BC with the canonization of the semi-circular form, all theatres tended to adopt this plan, immediately supplanting the rectilinear staircases in use up to that point. The existence of rectilinear staircases after the fifth century BC has always been refused by a greater number of scholars who indicate that the transition to the semi-circular plan was in the fourth century ${ }^{2}$. In reality, as shown by studies on the theatre of Makyneia, architects in small provincial cities often used solutions more suited to the morphological characteristics of the landscape, to available resources and to the needs of the city ${ }^{3}$. The theatre of Isthmia ${ }^{4}$ also seems datable to about $400 \mathrm{BC}$, the start of the fourth century BC. We might say the same for the theatre of Eretria, where the studies by Fiechter ${ }^{5}$ now appear to displaced by Isler, who dates the rectilinear structure to the mid-fourth century ${ }^{6}$. This debate, still heated and animated, highlights how much we have yet to understand when it comes to theatres. The constant restoration and renovation performed on the theatres over the centuries cancels out the original image of these structures. The result, in a way, is a loss of data we might have used to establish and refer to aspects shared by these early theatres. The archaeological evidences examined to date seem to start from a common feature: all of these theatres were built directly into rocky slopes ${ }^{7}$. Another feature seems to be

${ }^{1}$ Paga J. The Greek Theatre, in Margaret M. Miles (ed.), A Companion to Greek Architecture, Chichester, West Sussex. - P. 371.

${ }^{2}$ On this subject, also see Paga J. Deme Theaters in Attica and the Trittys System, in Hesperia, 2010, 79. - PP. 351-371.

${ }^{3}$ Stiros S., Psimoulis P.A., Kolonas Ch.L. The Theatre of Aitolian Makyneia, in Annual of the British School at Athens, 2005 (2006), 100. - P. 312.

${ }^{4}$ Gebhard E. The theatre at Isthmia, Chicago and London 1973. - PP. 9-26; Moretti J.C. Les entrées en scène dans le théâtre grec: l'apport de l'archéologie, in Pallas, 1992. - PP. 84-87.

${ }^{5}$ Fiechter E.R. Das Theater in Eretria, Stuttgart 1937.

${ }^{6}$ Isler H.P. Eretria, in P. Ciancio Rossetto, G. Pisani Sartorio (a cura di), Teatri greci e romani alle origini del linguaggio rappresentato. Censimento analitico, Roma 1994. PP. 215-216; Isler H.P. Das Theater: Grabungen 1997 und 1998, in Eretria XVIII, Gollion 2007.

${ }^{7}$ Moretti J.C. Le théâtre du sanctuaire de Dionysos Éleuthéreus à Athènes, au Ve s. av. J.-C., in REG, 113, 2000. - P. 283. 
the absence of a stable scenic structure (skene) ${ }^{1}$. A rectilinear shaped and rather small koilon is a recurring element in the theatres of Greece and Sicily in the fifth and early fourth century. During the fourth century, with the start of the Hellenistic age and an increased importance of the theatre in Greek society, these koila began to have larger dimensions ${ }^{2}$. Anti and Polacco ${ }^{3}$ previously believed theatre of Chaeronea (fig. 1 ) to be a small theatre with $8 / 12$ rectilinear steps. Recent surveys performed on the structure reveal that its early form likely had at least ten rows of steps of which we have traces in loco ${ }^{4}$, followed by a unknown number of other steps which vanished with the construction work for the cavea's curvature. A more exact dating of this structure comes not only from a comparison with other rectilinear plan theatres, but also from an inscription seen and recorded first, mistakenly, by Frazer ${ }^{5}$ and later, correctly, by the two Italian schol$\operatorname{ars}^{6}$. It now seems rather improbable to trace the inscription recorded in the $\mathrm{IG}^{7}$ to the wall of the katatomé $\mathrm{A} 3$ (v. fig. 2):

$$
\begin{gathered}
{[---] \mu \varepsilon \sigma[--]} \\
\text { Ev̉[F] } \alpha \dot{\alpha} \nu \delta \rho \varsigma .
\end{gathered}
$$

${ }^{1}$ The theatre of Isthmia is an exception, where we seem to have the remains of a scenic structure. Gebhard E. The theatre at Isthmia, Chicago and London 1973. PP. 9-26.

${ }^{2}$ Paga J. Deme Theaters in Attica and the Trittys System, in Hesperia, 2010, 79. P. 367.

${ }^{3}$ Mentions of the theatre are also found in a work by Ginouvès. However, he states in a note that his considerations on the theatre are the result of reading the work by Anti and Polacco, (Ginouvès R. Le théâtron à gradins droits de l'odéon d'Argos, Paris, 1972. - PP. 62-63). To be mentioned, also: Arias P.E. Il teatro Greco fuori di Atene, Firenze 1934. - PP. 64-66; Dilke O.A.W. The greek theatre cavea, in BSA 43, London 1948. - PP.125-192.

${ }^{4}$ Anti and Polacco detected only 8 steps, while a fresh autoptic examination of the structure found the remnants of at least 10 steps, under which other staircases, which disappeared following the curvature of the koilon, could be identified.

${ }^{5}$ This inscription, IG 3459, was mistaken by Frazer with IG 3407, causing numerous problems in archaeological literature in the following years. It held, on the basis of the dedication contained in IG VII 3407, that the theatre could have been dedicated to Apollo and Artemis. Frazer J.G. Frazer, Pausanias's Description of Greece, V. London, 1898. - PP. 205-208; The transcription error is still evident

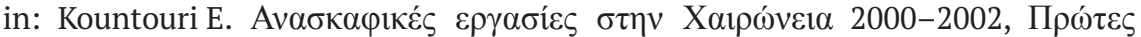

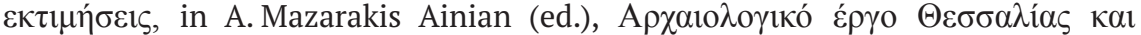

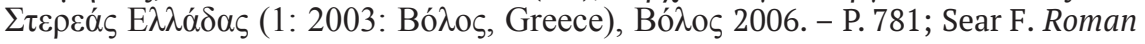
Theatres. An Architectural Study, Oxford 2006. - P. 392.

${ }^{6}$ Anti C., Polacco L. Nuove ricerche sui teatri greci arcaici, Padova 1969. - P. 25.

${ }^{7}$ IG VII 3459. 


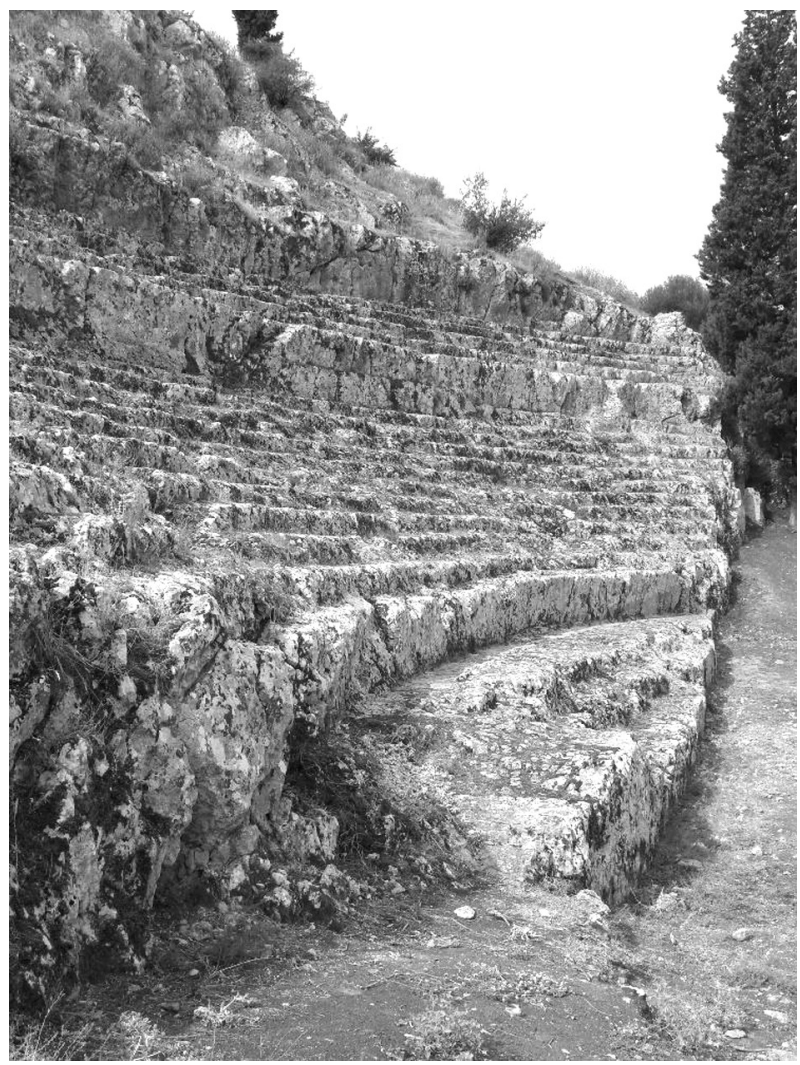

Fig. 1. Chaironeia, theatre

This evidence was examined rather hastily by Anti and Polacco. The two archaeologists reported seeing it carved in the centre of the katatomè K3 (fig. 2). The epigraphic text, despite its insignificant content, is interesting for the presence of " $F$ ". As noted by Buck ${ }^{1}$, the " $F$ " in an intervocalic position is attested in Boeotia only until the first half of the fourth century BC, at most. This dating provides us with an excellent chronological marker to reconstruct the steps related to the curvature of the cavea. The text was certainly engraved on a rectilinear wall of the koilon. The redefinition of the cavea, according to Anti and Polacco, was completed at the turn of the fourth and third century, therefore, at least, 50 years after the " $F$ " is sup-

\footnotetext{
${ }^{1}$ Buck C.D. The Greek dialects. - Boston, 1910. - PP. 48-49; id. Buck C.D. Introduction to the study of the Greek dialects: grammar, selected inscriptions, glossary. - Boston, 1928. - PP. 196.
} 


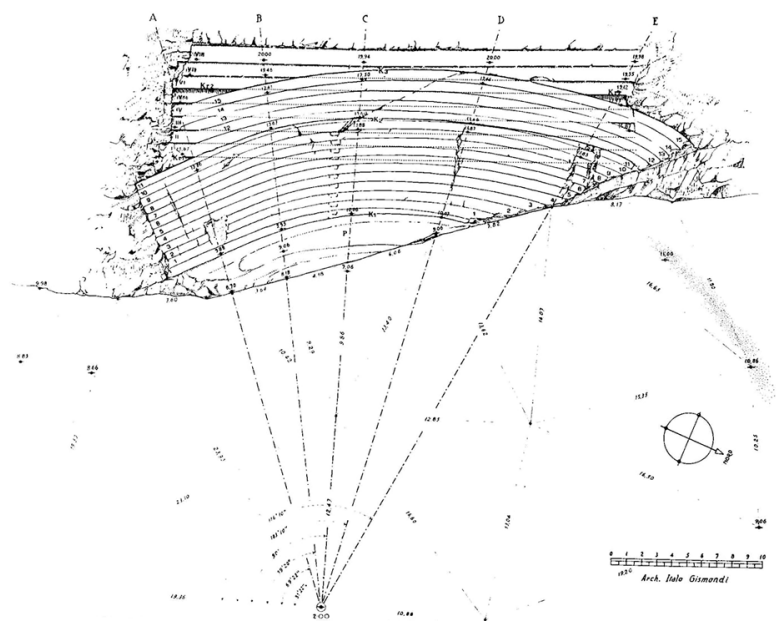

Fig.2. Chaironeia, theatre plan, Gismondi 1969 (Anti Polacco 1969)

posed to have disappeared. So, it would seem rather unlikely to find a text that paleographically dates back to the first half of the fourth century BC, at most, on a (curved) reworked wall at the end of the fourth century BC, like the katatomè $\mathrm{K} 3$. The only point where this katatomè coincides with the ancient step, and where its surface could have remained unchanged, is a very small area, somewhat high compared to the step's level, located almost at the centre of this wall. Autoptic analysis carried out in oblique light, however, did not reveal any traces. In addition to the problem of the inscription, the theatre of Chaeronea seems to have another problem: the height of the orchestra in the early rectilinear-plan theatre. If we accept the idea that this early structure was designed with few steps, as shown in the plan prepared by Gismondi in 1969, we understand that the original plan for the orchestra must have been at a higher level than the orchestra of the curvilinear theatre. So, to create the curvilinear theatre, the koilon would have been expanded, which would have involved excavation works to the original plan and a lowering to create more steps, which then became part of the ima cavea. It seems more likely, then, that the original rectilinear staircase took up the same height that was covered by the curvilinear theatre ${ }^{1}$. This is confirmed by observable details in the shape of

\footnotetext{
${ }^{1}$ Anti and Polacco themselves, considering the possibility of a theatre with only the 8 rectilinear steps they found, admitted to having problems with this hypothesis, due to the absence in situ of containment and substructure works on the orchestra level which were found about 7 metres above the current one. This is why they
} 


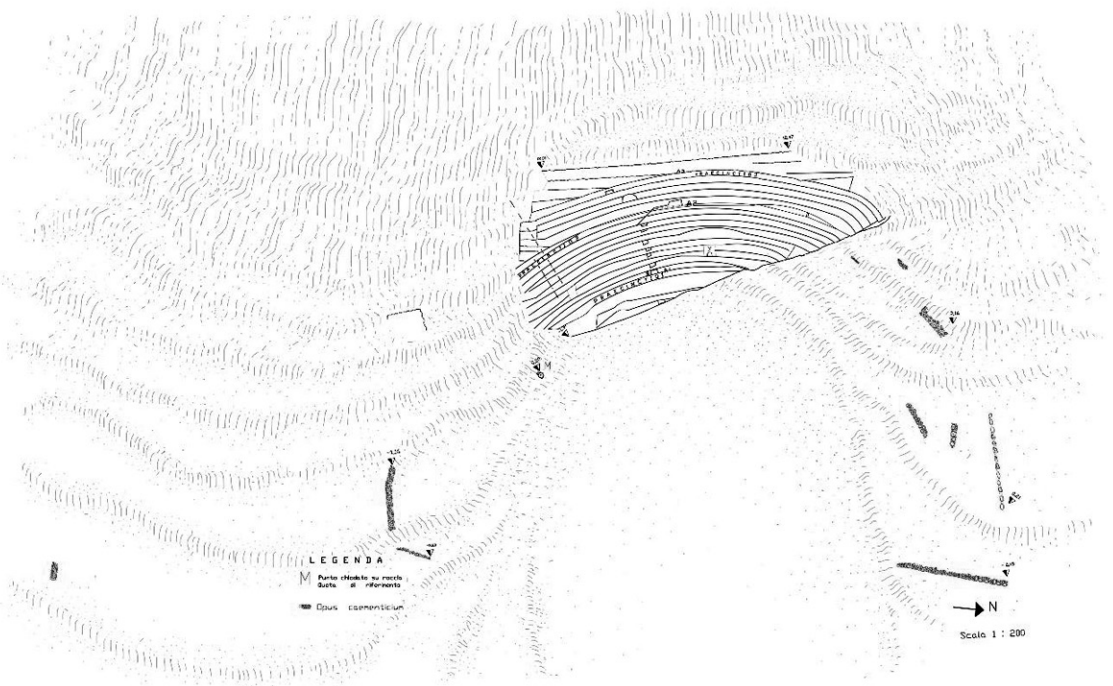

Fig. 3. Chaironeia, theatre plan, Germani 2012

some of the steps in the ima cavea, as well as by surveys conducted in 2009 (fig. 3). This new theatre, equipped with two side wings on the embankment, continued to function until at least the mid-fourth century $\mathrm{AD}^{1}$, as evidenced by coins found in recent excavations ${ }^{2}$. The continuity of this structure is also attested by an inscription ${ }^{3}$, dated to the third century BC,

suggested a series of about 4 steps to be placed under a katatomé kr1 (Gismondi 1969 plan). This katatomè separated the rectilinear staircase, made up of the 8 steps they detected, from a lower set of steps (perhaps 4) used to reach the current orchestra level.

${ }^{1}$ The throne held in the church of Kimisi Theotokou in the modern village of Chaeronea, dated to the mid-fourth century $A D$, would suggest a very long lifespan for this structure, if its provenience from the proedria of the theatre were confirmed. Germani M. Troni e sedili della Beozia con decorazioni vegetali, in R. Di Cesare, F. Longo, S. Privitera (a cura di), Dromoi, Studi sul mondo antico offerti a Emanuele Greco dai suoi allievi della Scuola Archeologica Italiana di Atene, Salerno 2016. - PP. 231-241.

${ }^{2}$ These are, in fact, two coins datable to the rule of Constantius II; while the first is a Centenionalis with an effigy of Constantius on the front and a soldier killing scene on the back (RIC352; Cohen H., Description historiques des monnaies frappée sous l'Empire Romain, Paris, 1880-82. - P. 46), the second, not as well preserved, seems to refer to the Maiorina type, with the diademed head of the emperor on the front and a knight killing a barbarian on the back (RIC VIII \#195).

${ }^{3}$ IG VII 3409. 


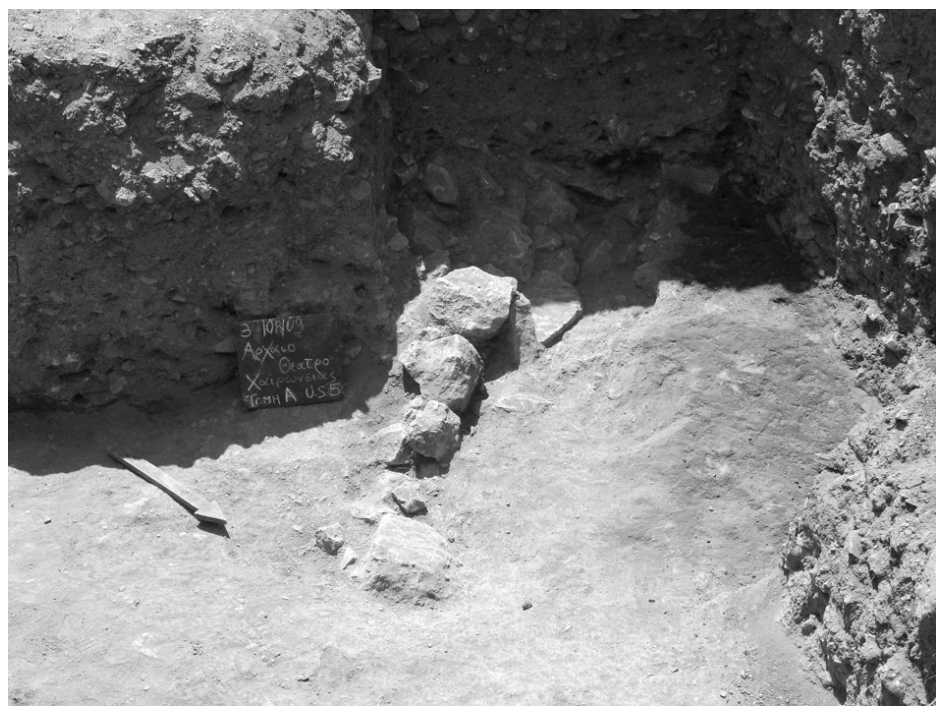

Fig. 4. Chaironeia, excavations 2009, trench in the orchestra of the theatre

which references construction work for a proskenion. This information is interesting because it attests that the theatre was in use and that performances were regularly held in it in the third century BC. Unfortunately, neither direct recognition nor the excavations made in $2009^{1}$ allow us to find the remains of a skene. In the last century, the theatre area was subjected to significant modification, which compromised its original morphology. The archaeological trench opened at the edge of the orchestra did not yield any evidence of structures that may refer to the proskenion mentioned in the inscription ${ }^{2}$. At approximately $2.5 \mathrm{~m}$ below ground level, instead, a dry stone wall was found. Due to the closure of excavations, however, it was not possible to fully investigate (fig. 4). The remnants, which are perpendicular to the cavea of the theatre, although they are minimally included in the trench, do not seem to be connected with the theatre itself. Thanks to a few mixed ceramic fragments found in the same strata as the stone structure, this situation seems datable to before the creation of the theatre itself. This condition helps us understand how the ancient plan underwent a gradual raising of roughly $2.50 \mathrm{~m}$. As regards the scenic

${ }^{1}$ Germani M. Il teatro di Cheronea: dal koilon rettilineo alla cavea semi circolare, in M. Germani (a cura di) Tra Oriente ed Occidente: miscellanea di studi sul mondo antico, Aquino 2017. - PP. 48-62.

${ }^{2}$ Germani M., 2017, op. cit. note 1. - P. 58. 
structure, without precise archaeological data, we might suppose that the theatre still lacked a skene in the third century BC and that the proskenion referred to in the inscription was just a raised wooden structure. This still occurred in many theatres between the late Classical age and the dawn of the Hellenistic period, only when performances were held. The issue of the koilon's curvature still requires clarification. When was the rectilinear theatre of Chaeronea curved to align with the model of Hellenistic theatres? According to Anti and Polacco, the curvature of the staircase was done in two later phases, with about three centuries between them. The theatre must have undergone an early rearrangement of the theatron just after the Battle of Chaeronea in 338 BC. This intervention gave the koilon the curvilinear style mentioned above, which scholars believe to be fundamental in indicating the small Boeotian town's reception of the new model. The definitive curvature, according to the two Italians, occurred after the 86 BC battle between Sulla and Archelaus ${ }^{1}$. In reality, the pseudo semicircular form adopted after the theatre of Chaeronea's curvature does not make any sense unless it is considered in light of the two embankments on the sides of the koilon carved in the rock. The need to explain the various katatomai in the theatre led the two Italians to identify two later actions of curvature to the koilon, which now no longer seem probable ${ }^{2}$.

In the absence of concrete structures to underbuild and contain the two side embankments at the edge of the flight of steps, no partial curvature of the koilon could have guaranteed its alignment to the new standards set by the theatron of the Epidaurus theatre. It seems clear, rather, that the theatre of Chaeronea adopted its pseudo-circular shape only after the creation of the two side embankments. The hurried curvature created for the koilon in the rock cannot be justified if not based on concrete structures found to the north and south of the cavea, to expand the original koilon. For this reason, I believe it is more likely that the curvature of the koilon

\footnotetext{
${ }^{1}$ Anti, Polacco 1969: C. Anti, L. Polacco, Nuove ricerche sui teatri greci arcaici, Padova 1969. - PP. 43-44.

${ }^{2}$ Other hypotheses on the transformation of the structure into an arena and on the subsequent raising of the first steps of the cavea with respect to the orchestra level also seem improbable. A test performed during 2009 excavations at the foot of the staircase highlighted, a few $\mathrm{cm}$ from the level of the first step, the presence of a rocky bank. This discovery suggests that the original orchestra level, removed from the heavy excavation work completed in the 60 s of the century before, must have been located above this rock and could have been made up of a strong mixture that concealed and levelled the natural roughness (holes) of the rocky bank. Germani M. Il teatro di Cheronea: dal koilon rettilineo alla cavea semi circolare, in M. Germani (a cura di) Tra Oriente ed Occidente: miscellanea di studi sul mondo antico, Aquino 2017. - PP. 48-62.
} 
influenced the structure only after the spread of opus caementicium in Greece, which was widespread between the end of the first century BC and the start of the following century ${ }^{1}$. Chaeronea's archaeologically-attested demographic boom in the Roman age, together with the construction ex novo ${ }^{2}$ of public buildings ${ }^{3}$, seems to support the hypothesis that theatre building was redefined in that period. It was thus the need to expand the capacity of the old, smaller koilon that stimulated the redefinition of the entire building towards the circular shape. Therefore, it seems that for roughly four centuries, it continued to function with a rectilinear plan.

${ }^{1}$ Such a late date for the reception of the new model shouldn't surprise us. Remember, for example, that in the small theatre of Argo, the rectilinear phase of the mid-fifth century BC was cancelled out only with the construction of the odeon built at the end of the first century $\mathrm{AD}$ and the start of the second. Nielsen I. Cultic Theatres and Ritual Drama, Gylling, 2002. - PP. 101-106; Burmeister E. Antike griechische und römische Theater, Darmstadt, 2006. - P. 129; Isler H.P. Argo, in P. Ciancio Rossetto, G. Pisani Sartorio (a cura di), Teatri greci e romani alle origini del linguaggio rappresentato. Censimento analitico, Roma 1994. - P. 123.

${ }^{2}$ Kahrstedt U. Das wirtschaftliche Gesicht Griechenlands in der Kaiserzeit: Kleinstadt, Villa und Domäne, Bern, 1954. - PP. 108-109; ADelt., 51, 1996, Xpovıќ́,

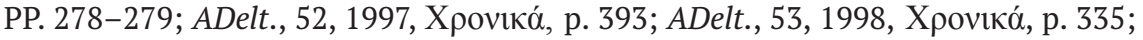
Bonanno M. La scultura di età romana nella Beozia: importazioni e produzioni

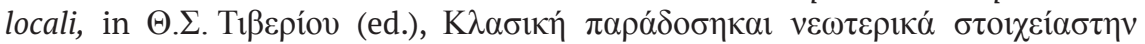

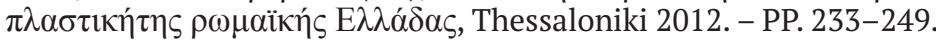

${ }^{3}$ The two public bath buildings identified by excavations in the Kaili and Tsirka properties, in addition to the numerous remains of production villas, often equipped with bath systems, seem to indicate a particularly flourishing period for the city starting at the end of the first century BC. ADelt., 22, 1967, Xpoviкó, p. 243; ADelt., 48, 1993, Xpoviкá, pp. 181-182; Andriomenou A.K. s.v. Chaironeia,

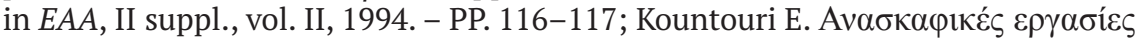

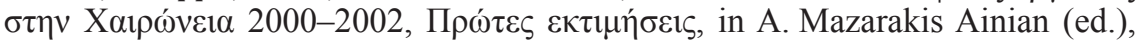

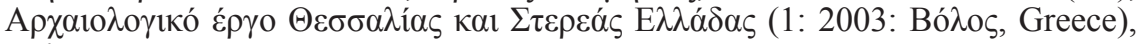
Bódos 2006. - P. 786; Harami A. The excavation of a Roman building in Chaeronea, in M. Germani (ed) Tra Oriente ed Occidente: miscellanea di studi sul mondo antico. Frosinone 2016. - PP. 21-35. 